\title{
Fractionation of Heavy Metals in the Metal Contaminated Soils Amended with Humic Acids
}

\author{
Bülent Topcuoğlu
}

\begin{abstract}
A greenhouse pot experiment was carried out to study the effects of humic acids (HA) on the heavy metal bioavailability and metal fractionation of metal treated soil. An uncontaminated calcareous soil was treated with heavy metals $(\mathrm{Zn}$, $\mathrm{Cu}, \mathrm{Ni}, \mathrm{Pb}$ and $\mathrm{Cd}$ ) and humic acid was applied to these metals applied soils at $0 \%$ (control) and $2 \%$, rates. After 8 weeks of incubation, attriplex canences, a phytoremediation plants were cultured on these soils and at the end of experiment the DTPA extractable heavy metals and metal fractions of the soils were analysed.

Metal treatments increased DTPA extractable metals and water soluble, exchangeable metal contents. Soil application of HA increased DTPA-extractable/bioavailable levels of $\mathrm{Zn}, \mathrm{Cu}, \mathrm{Ni}, \mathrm{Pb}$ and $\mathrm{Cd}$ in the soil compared to the in all treatments. Also $\mathrm{HA}$ application increased mainly organic bound and water soluble and acid soluble metal fractions, and increased mobility of all metals. Results showed that humic acid applications could be used in phytoremediation studies to increase phytoremediation efficiency in contaminated soils.
\end{abstract}

Keywords - Bioavailability, Fractionation, Humic acid, Soil Metals, Mobility

\section{INTRODUCTION}

Heavy metals are of considerable concern due to their toxicity, wide sources, non-biodegradable properties and accumulative behaviours [1]. Heavy metal pollution of agricultural soil is one of the most serious environmental problems and has significant detrimental effects on human health. Due to intensive use of agrochemicals in agricultural soils, some industrial activities heavy metals are become to common pollutants in agricultural soils and adjacent environment. Although some engineering techniques may efficiently be used to clean up the contaminated soils, most of them are expensive and sophisticated technologies, and they used for small scale contaminated areas [2].

The maximum permissible concentrations of heavy metals in contaminated soils are normally based on total concentration, although it is the bioavailable metal fraction that posses environmental concern [3]. Nevertheless, these criteria are insufficient since mobility, environmental diffusion and bioavailability largely depend on soil physico-chemical characteristics and, likewise, on trace metal chemical forms [4]. From an environmental point of view, the evaluation and forecast of food contamination is related to the bioavailable

Bülent Topcuoğlu, Professor, Soil Science and Plant Nutrition, Akdeniz University Vocational School of Tecnical Sciences, Antalya, TURKEY. fraction of heavy metals in soil.

Bülent TOPCUOĞLU is with the Akdeniz University Vocational School of Technical Sciences, 07058 Antalya TURKEY (phone: 0090242-3106751; fax: 0090242-2274785; e-mail: btoglu@ akdeniz.edu.tr).

The bioavailability of metals in soil is affected by numerous factors, such as cation exchange capacity, $\mathrm{pH}$ values of the soil, excess amounts of fertilizers, and chelators. These may all be manipulated to improve heavy metal phy-toextraction. Although phytoremediation has revealed great potential and synthetic chelators have shown positive effects in enhancing heavy metal extraction through phytoremediation, a vast num $\neg$ ber of negative side-effects was revealed and need therefore exist for low cost-effective and environmental friendly materials as an alternative to synthetic chelators [5].

As an alternative to synthetic chelators wide $\neg$ spread natural sources, found in soils, natural waters, sea sediment plants, lignite, oxidized bituminous coal, leonardite and gyttja sediments such as humic substances, could be used [6]. The term humic substances refers to a category of naturally occurring organic materials result from the decomposition of plant and animal residues [7]. Humic acids (HA) contain acidic groups such as carboxyl and phenolic $\mathrm{OH}$ functional groups [8] and, therefore, provide or $\operatorname{cganic}$ macromolecules with an important role in the transport, bioavailability, and solubility of heavy metals [9].

The aim of this research was to assess the ability of HA on the bioavailability and metal fractionation of heavy metals $(\mathrm{Zn}, \mathrm{Cu}$, $\mathrm{Ni}, \mathrm{Pb}$ and $\mathrm{Cd}$ )from metal polluted soil under greenhouse controlled conditions.

\section{MAterials AND MethodS}

\section{A. Soil charactarization and analysis}

The contaminated soil used in this experiment was sampled from a red mediterranean soil, representative of the major agricultural areas of Turkey Antalya Aksu. Greenhouse soil samples were taken at a depth of 0 to $20 \mathrm{~cm}$ and these were air-dried, sieved $(<2 \mathrm{~mm})$ and stored in polyethylene bags sealed awaiting analysis. Electrical conductivity (EC) and $\mathrm{pH}$ were measured a soil: water ratio of 1:2. cation exchange capacity (CEC) was determined by $0.1 \mathrm{M}$ NN4AoC extraction; $\mathrm{CaCO} 3$ content was determined by the calcimeter; organic carbon was measured by wet oxidation; and texture was determined by Bouyoucos hydrometer method. For the 
determination of 'total' heavy metal concentrations, soil were digested in aqua regia $\left(1: 3 \mathrm{HNO}_{3} / \mathrm{HCl}\right)$ according to the international standard [8]. Bioavailable fractions of metals were extracted from soil with diethylenetriaminepentaacetic acid- $\mathrm{CaCl}_{2}$-triethanolamine adjusted to $\mathrm{pH} 7.3$ (DTPA) procedure [10]. The main analytical characteristics of the unpolluted experimental soil are shown in Table 1 which also shows the pollutant limits of soil permitted by EU legislation [10].

TABLE I

THE ANALYTICAL CHARACTERISTICS OF THE EXPERIMENTAL SOIL BEFORE APPLICATIONS

\begin{tabular}{|c|c|}
\hline \multicolumn{2}{|l|}{ Parameters } \\
\hline Texture Grade & Loam \\
\hline $\mathrm{pH}-\mathrm{H}_{2} \mathrm{O}(1: 5 \mathrm{w} / \mathrm{v})$ & 7.22 \\
\hline $\mathrm{CaCO}_{3}, \%$ & 4,45 \\
\hline Organic matter, $\%$ & 4,25 \\
\hline Clay,\% & 10,2 \\
\hline $\mathrm{CEC}, \mathrm{cmol} \mathrm{kg}^{-1}$ & 18,7 \\
\hline $\mathrm{EC}, \mathrm{dS} \mathrm{m}^{-1} 25^{\circ} \mathrm{C}$ & 0,71 \\
\hline Total N, \% & 0,105 \\
\hline $\mathrm{P}(\mathrm{ex}), \mathrm{mg} \mathrm{kg}^{-1}$ & 14,2 \\
\hline $\mathrm{K}(\mathrm{ex}), \mathrm{mg} \mathrm{kg}^{-1}$ & 78 \\
\hline $\mathrm{Ca}(\mathrm{ex}), \mathrm{mg} \mathrm{kg}^{-1}$ & 741 \\
\hline $\mathrm{Mg}(\mathrm{ex}), \mathrm{mg} \mathrm{kg}^{-1}$ & 132 \\
\hline Total $\mathrm{Zn}, \mathrm{mg} \mathrm{kg}^{-1}$ & $51,2(150-300)^{*}$ \\
\hline Total $\mathrm{Cu}, \mathrm{mg} \mathrm{kg}^{-1}$ & $8,5(50-140) *$ \\
\hline Total $\mathrm{Ni}, \mathrm{mg} \mathrm{kg}^{-1}$ & $6,9(30-75)^{*}$ \\
\hline Total $\mathrm{Pb}, \mathrm{mg} \mathrm{kg}^{-1}$ & $14,8(50-300)^{*}$ \\
\hline Total $\mathrm{Cd}, \mathrm{mg} \mathrm{kg}^{-1}$ & $0,01(1-3)^{*}$ \\
\hline
\end{tabular}

Sequental extraction method [11] was applied to soil samples to identify metal fractions. The heavy metal sequential extraction procedure had the following steps:

F1. $1 \mathrm{M} \mathrm{MgCl}_{2}(1: 8 \mathrm{w} / \mathrm{v}, \mathrm{pH} 7)$ for $1 \mathrm{~h}$ at room temperature; metals in soil solution and in exchangeable forms.

F2. $1 \mathrm{M} \mathrm{NaOAc}(1: 8 \mathrm{w} / \mathrm{v}, \mathrm{pH} 5)$ for $5 \mathrm{~h}$ at room temperature; metals mainly in the carbonate fraction.

F3. $0,04 \mathrm{M} \mathrm{NH} \mathrm{H}_{2} \mathrm{OH} / \mathrm{HCl}$ in $25 \%(\mathrm{v} / \mathrm{v}) \mathrm{HOAc}(1: 20 \mathrm{w} / \mathrm{v})$ for $6 \mathrm{~h}$ at $96{ }^{\circ} \mathrm{C}$; metals associated with $\mathrm{Fe}$ and $\mathrm{Mn}$ oxides.

F4. $3 \mathrm{ml} 0,02 \mathrm{M} \mathrm{HNO}_{3}+5 \mathrm{ml} 30 \% \mathrm{H}_{2} \mathrm{O}_{2}(\mathrm{pH} 2)$ for $3 \mathrm{~h}$ at $85^{\circ} \mathrm{C}$; metals associated with organic matter.

F5. HNO3-HCl digestion; residual fraction.

For the determination of total, bioavailable and sequential extracted metal concentrations, soil samples were digested in aqua regia $\left(1: 3 \mathrm{HNO}_{3} / \mathrm{HCl}\right)$ and $\mathrm{HCLO}_{4}$ according to the international standard [8]. $\mathrm{Zn}, \mathrm{Cu}, \mathrm{Ni}, \mathrm{Pb}$ and $\mathrm{Cd}$ concentrations of greenhouse soil samples were analysed using ICP-MS under optimised measurement conditions, and values were adjusted for oven dried $\left(12 \mathrm{~h}\right.$ at $\left.105^{\circ} \mathrm{C}\right)$ material.

\section{B. Extraction of humic substances and addition to soils}

Leonardite is a low-rank coal with significant amounts of humic materials, mainly humic acids. Leonardite was treated with an aqueous solution of $0.5 \mathrm{M} \mathrm{NaOH}(1: 5 \mathrm{w}: \mathrm{v})$. The residue was further extracted two more times for $1 \mathrm{~h}$ by the same extraction solution. The supernatants were filtered through glass wool, combined, and brought to $\mathrm{pH} 1$ with concentrated $\mathrm{HCl}$ and the precipitated $\mathrm{HA}$ allowed settling for $24 \mathrm{~h}$. The precipitate was separated from the soluble fraction (fulvic acids) by centrifugation at $4000 \mathrm{rpm}$ for $20 \mathrm{~min}$, and washed 2-3 times with deionised water at a ratio of 1:3. The washed precipitate was transferred into a round bottom flask, freezed and lyophilised. The freeze-dried HA was suspended in water and then dissolved to $\mathrm{pH} 7$ by adding $0.5 \mathrm{~N} \mathrm{NaOH}$ stepwise. The humic acid solution was brought to volume in order to reach a final HA concentration of $25 \mathrm{mg} \mathrm{ml}^{-1}$ [12].

\section{Experimental Design}

A factorial experiment was conducted in randomized complete block design including 2 levels of humic acid (control treatment and \% 2 humic acid tretament) and 2 levels of heavy metals (control treatment and 300, 140, 75, 300 and $3 \mathrm{ppm}$ concentration of $\mathrm{Zn}, \mathrm{Cu}, \mathrm{Ni}, \mathrm{Pb}$ and $\mathrm{Cd}$, respectively) with 5 replications. Ten kilograms of air-dried and sieved soil were filled into plastic pots. A pot-plate was placed under each pot to prevent leaching. Basic N-P-K fertilization was applied to experimental soil at the rate of 100,50 and $100 \mathrm{mg} \mathrm{kg}^{-1}$ of N (as $\mathrm{NH}_{4} \mathrm{NO}_{3}$ ), $\mathrm{P}$ (as $\mathrm{KH}_{2} \mathrm{PO}_{4}$ ) and $\mathrm{K}$ (as $\mathrm{K}_{2} \mathrm{SO}_{4}$ ). Heavy metals $\mathrm{Zn}$, $\mathrm{Cu}, \mathrm{Ni}, \mathrm{Pb}$ and $\mathrm{Cd}$ were added to experimental soil as metalic salt solutions (as $\mathrm{Zn}\left(\mathrm{NO}_{3}\right)_{2}, \mathrm{CuSO}_{4}, \mathrm{Ni}\left(\mathrm{NO}_{3}\right)_{2}, \mathrm{~Pb}\left(\mathrm{NO}_{3}\right)_{2}$, $\mathrm{Cd}\left(\mathrm{NO}_{3}\right)_{2}$, respetively). Metal concentrations were designed to maintain maximum metal limits of European Union [10] . A uniform application was obtained by homogenization of the soil. The soil was subsequently incubated in the green house for 8 weeks before experiment. During these 8 weeks the soil was watered 1-2 times a week with deionised water to maintain field capacitiy of water. After that an phytoremediation plant, Atriplex canescens (Pursh) Nutt were grown at 2 months. After harvesting, soil samples were collected from each pot for above mentioned analysis.

\section{Metal Mobility Factor}

Due to some metal forms are strongly bound to soil components than those extracted in F1 and F2, the mobility of metals in soil samples may be evaluated on the basis of absolute and relative content of fractions weakly bound to soil component. Mobility of soil metal was computed based on the metal fractions theoretically mobile fractions in sequential extraction procedure, where the metals are softly bound to the solid phases. Relative index of metal mobility was calculated as a 'mobility factor' (MF) on the basis of the following equation:

$$
\mathrm{MF}: \frac{\left(\mathrm{F}_{1}+\mathrm{F}_{2}+\mathrm{F}_{\mathrm{a}}\right)}{\left(\mathrm{F}_{1}+\mathrm{F}_{2}+\mathrm{F}_{\mathrm{a}}+\mathrm{F}_{4}+\mathrm{F}_{5}\right)} \times 100
$$

This equation is largely describes the potential mobility of metals [13]

One-way ANOVA test $(p \leq 0.05)$ calculated using the statistical package SPSS-16 for Windows program were applied to compare the differences in heavy metal concentrations in soils and in evaluation parameters.

\section{RESULTS AND DISCUSSION}

\section{A. DTPA extractable metal contents of soil}

Before the treatments experimental soil have generally slightly alkaline reaction, moderate CEC, high EC values and highly calcareous. Physical and chemical characteristics of greenhouse soil are well within the accepted normal range of 
agronomic values, and the heavy metal concentrations are below the levels indicated by the EU [10]. DTPA extractable metal concentrations of experimental soil after humic acid and metal treatments are presented in Figure 1 and Figure 2.

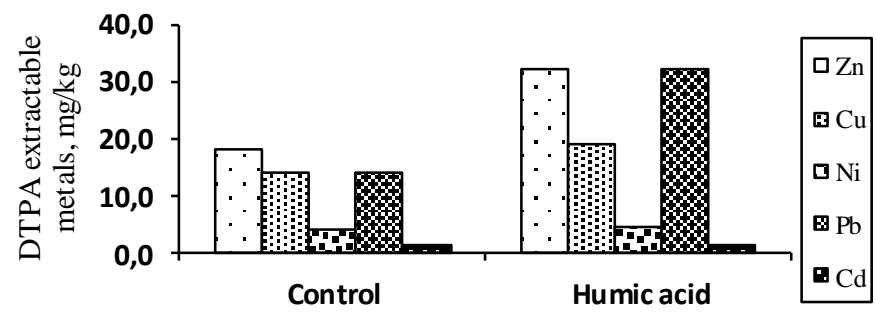

Fig. 1. DTPA extractable metal concentration in control soil and humic acid treated soil

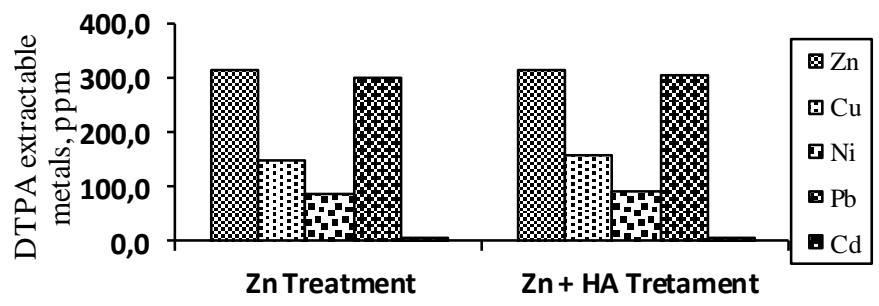

Fig. 2. DTPA extractable metal concentrations of soil in metal and metal+humic acid treatments

In this study, bioavailability of metals was expressed in terms of concentrations extractable with DTPA and means metals can be easily taken by the plants. As can be seen in Figure 1 and Figure 2, humic acid applications has brought about significant increases in DTPA-extractable $\mathrm{Zn}, \mathrm{Cu}, \mathrm{Ni}, \mathrm{Pb}$ and $\mathrm{Cd}$ concentrations both in control and metal treated soil. These data also confirm that humic substances added to soil are contributing in keeping the heavy metals in more bioavailable forms (Pitchell et al., 1999). Metal applications to the soil increased the amount of DTPA-extractable metals considerably. The tendency of DTPA extractable metal accumulation in soil was in the following order: $\mathrm{Zn}>\mathrm{Pb}>\mathrm{Cu}>\mathrm{Ni}>\mathrm{Cd}$.

\section{B. Soil Metal Fractionation}

Concentrations of $\mathrm{Zn}, \mathrm{Cd}, \mathrm{Ni}, \mathrm{Pb}$ and $\mathrm{Cd}$ in metal fractions of soil were given in Figures 3-11. Distribution of metals in control treatment showed that the greatest percentage of all metals was present in the residual fraction. The residual phase represents metals largely embedded in the crystal lattice of the soil fraction and should not be available for remobilization except under very harsh conditions [13]. In control treatment the distribution of metals in greenhouse soil samples generally followed the order below for the metals studied.

$\mathrm{Zn}: \mathrm{F} 1<\mathrm{F} 2<\mathrm{F} 3<\mathrm{F} 4<\mathrm{F} 5$

$\mathrm{Cu}: \mathrm{F} 1<\mathrm{F} 2<\mathrm{F} 3<\mathrm{F} 4<\mathrm{F} 5$

Ni: F1<F2<F1<F4<F5

$\mathrm{Pb}: \mathrm{F} 1<\mathrm{F} 3<\mathrm{F} 1<\mathrm{F} 4<\mathrm{F} 5$

$\mathrm{Cd}: \mathrm{F} 1<\mathrm{F} 2<\mathrm{F} 4<\mathrm{F} 3<\mathrm{F} 5$
Humic acid applications considerably increased heavy metal concentrations in soil fractions both in control and metal treated soil with the exception of F5 fraction. Also Soil metal applications applications shaply increased heavy metal concentrations in soil fractions with the exception of F5 fraction. Metals in F1, F2 and F4 fractions were markedly increased by both metal and humic acid applications. The exchangeable (F1) and acid-extractable fractions (F2) are considered to be easily soluble and available. Changes in F3 fraction with humic acid applications were very less. In metal treatments, the distribution of metals in soil samples generally followed the order below.

\section{$\mathrm{Zn}: \mathrm{F} 4<\mathrm{F} 2<\mathrm{F} 1<\mathrm{F} 5<\mathrm{F} 3$}

$\mathrm{Cu}: \mathrm{F} 4<\mathrm{F} 1<\mathrm{F} 2<\mathrm{F} 5<\mathrm{F} 3$

\section{Ni: $\mathrm{F} 4<\mathrm{F} 2<\mathrm{F} 1<\mathrm{F} 5<\mathrm{F} 3$}

$\mathrm{Pb}: \mathrm{F} 2<\mathrm{F} 1<\mathrm{F} 4<\mathrm{F} 5<\mathrm{F} 3$

Cd: $\mathrm{F} 1<\mathrm{F} 2<\mathrm{F} 4<\mathrm{F} 5<\mathrm{F} 3$

Although there was a consideration that humic acid-rich materials can be useful amendments for soil remediation involving stabilisation in calcareous soil [14]; these results show that humic acid has an ability to make soil metals in soluble or exchangable form. As can be expected soil metal applications increased F1 and F2 metal fractions due to the metal applications were in soluble metal salts forms. At the same time F4 fraction of metals that represents organic matter bound metals were increased by humic acid applications.

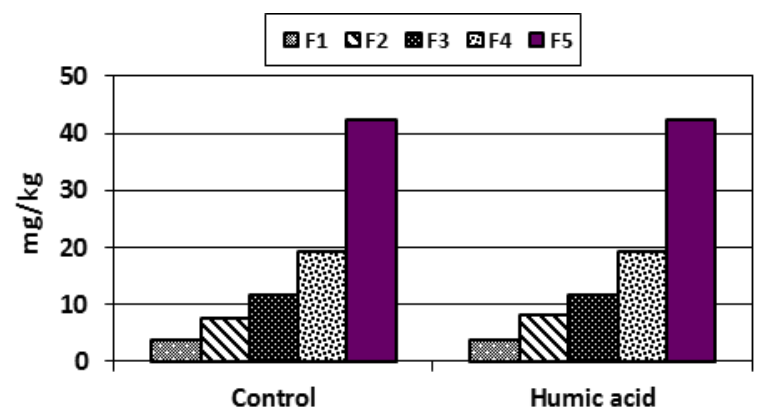

Fig. 3. Distrubution of Zinc fractions in the control and humic acid treated soil.

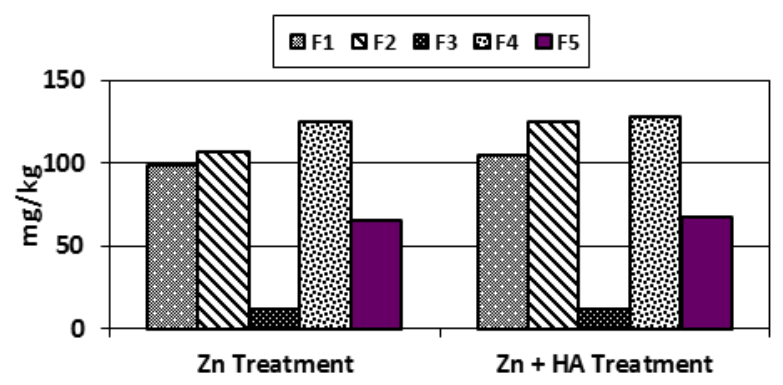

Fig. 4. Distrubution of Zinc fractions in the Zinc treated and $\mathrm{Zn}+$ humic acid treated soil. 


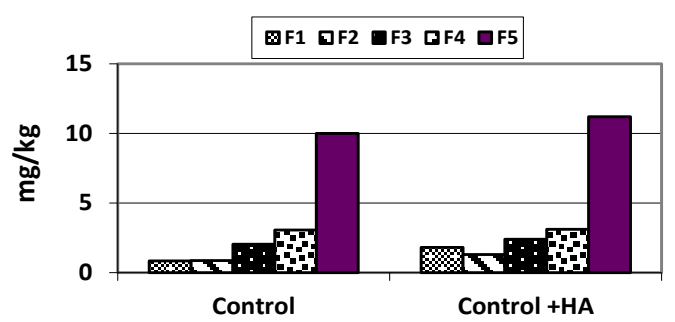

Fig. 5. Distrubution of Copper fractions in the control and humic acid treated soil.



Fig. 6. Distrubution of Copper fractions in the Copper treated and Copper + humic acid treated soil.

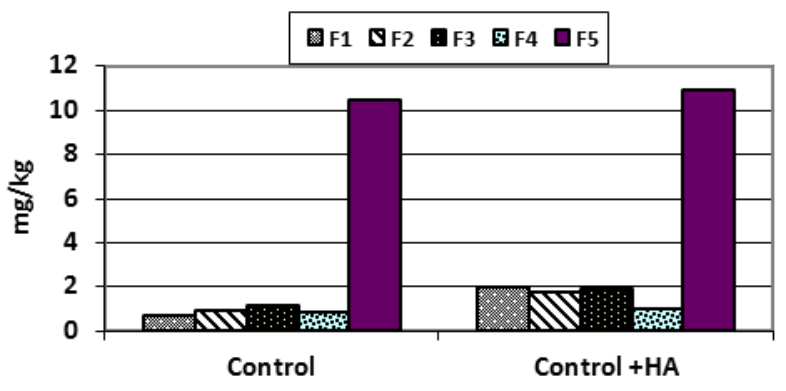

Fig. 7. Distrubution of Nickel fractions in the control and humic acid treated soil.

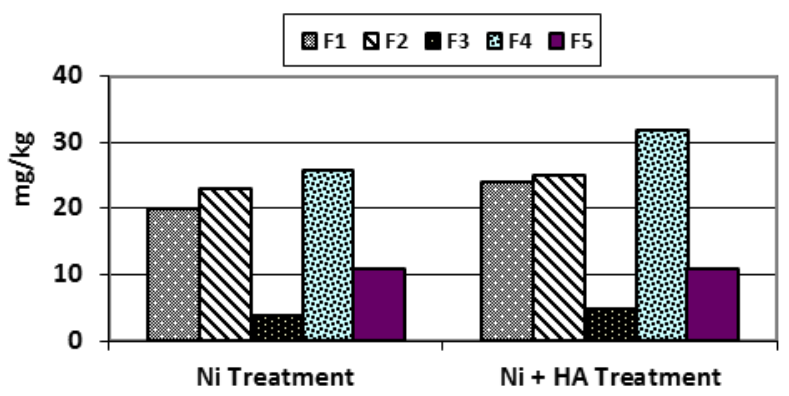

Fig. 8. Distrubution of Nickel fractions in the Nickel treated and Nickel + humic acid treated soil.

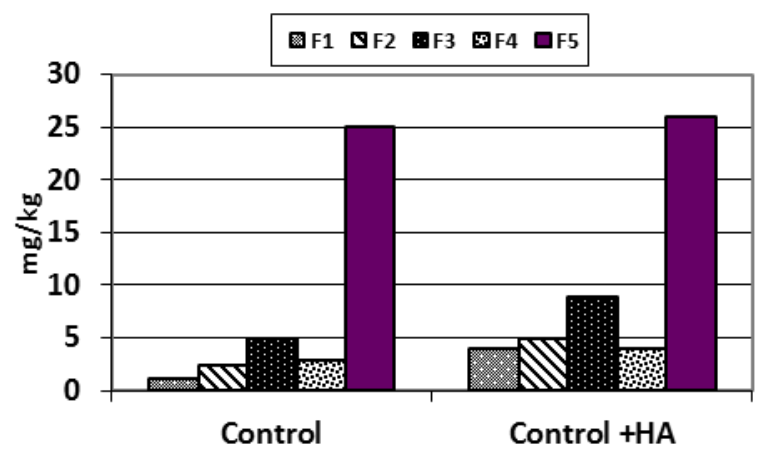

Fig. 9. Distrubution of Lead fractions in the control and humic acid treated soil.

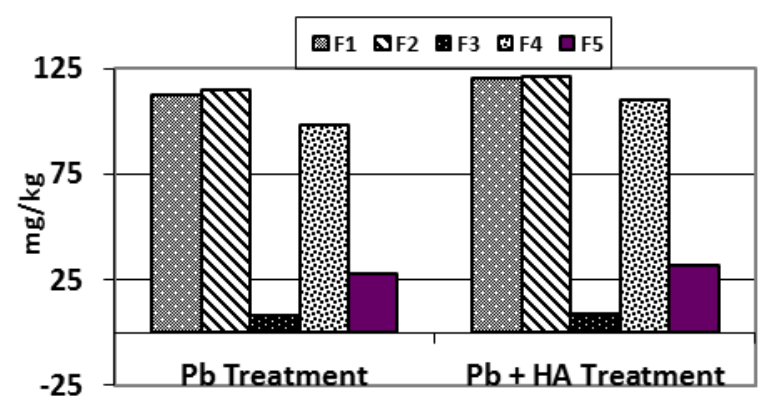

Fig. 10. Distrubution of Lead fractions in the Lead treated and Lead + humic acid treated soil.

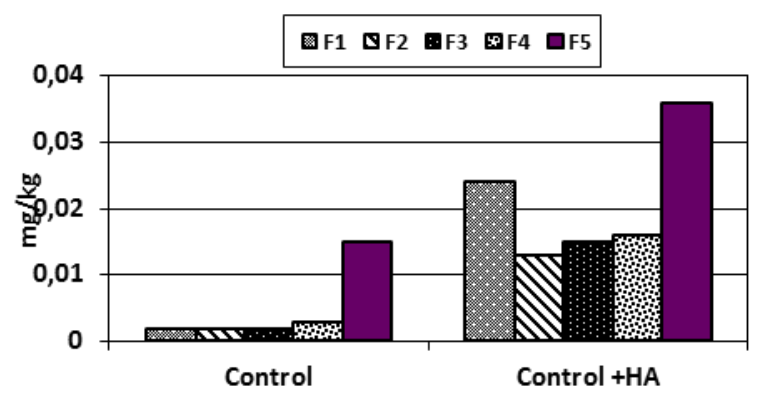

Fig. 11. Distrubution of Cadmiumfractions in the control and humic acid treated soil.

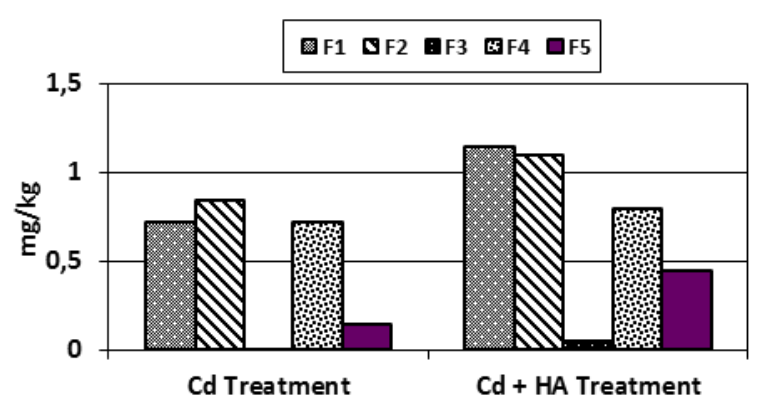

Fig. 12. Distrubution of Cadmium fractions in the Cadmium treated and Cadmium + humic acid treated soil. 


\section{Mobility of Metals}

This equation is largely describes the potential mobility of metals; expressed as mobility factor (MF) and the high MF values have been interpreted as symptoms of relatively high lability and biological availability of heavy metals in soils (15). The MF values in control soil were considerably higher for $\mathrm{Zn}$ and $\mathrm{Cd}$. Humic acid applications increased mobility factor value for all metals examined especially for $\mathrm{Pb}$ and $\mathrm{Cd}$ (Figure 13). Both in metal treatments and metal+humic acid treatments no statisticaly important relation with the exception of $\mathrm{Cd}$ was recorded for mobility factor of metals. This may be caused by the using of soluble salts of metals in treatments. The mobility of metals in humic acid and metal treated soils may be assessed on the basis of absolute and relative content of fractions weakly bound to soil components. The results of the present study suggest that the mobility of metals declines in the following order:

Control soil: $\mathrm{Zn}>\mathrm{Cd}>\mathrm{Pb}>\mathrm{Cu}>\mathrm{Ni}$

Humic acid treated soil: $\mathrm{Cd}>\mathrm{Pb} \geq \mathrm{Ni}>\mathrm{Cu}>\mathrm{Zn}$

Metal treated soil: $\mathrm{Cd}>\mathrm{Pb}>\mathrm{Ni}>\mathrm{Cu}>\mathrm{Zn}$

Metal +humic acid treated soil: $\mathrm{Cd}>\mathrm{Pb} \geq \mathrm{Ni}>\mathrm{Cu}>\mathrm{Zn}$



Fig.13. Metal mobility factors of control and humic acid applied soil.

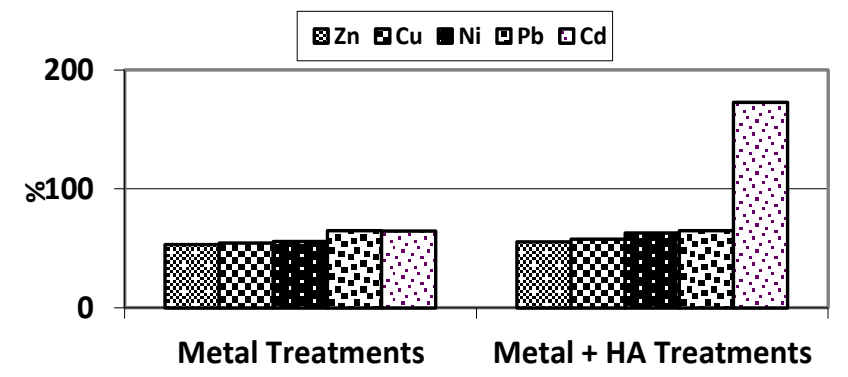

Fig.14. Metal mobility factors of soils treated with heavy metals and humic acid

\section{CONCLUSION}

The results of the present study indicates that soil application of HA increased DTPA-extractable/bioavailable levels of $\mathrm{Zn}, \mathrm{Cu}, \mathrm{Ni}, \mathrm{Pb}$ and $\mathrm{Cd}$ in the soil compared to the in all treatments. Also HA application increased mainly organic bound and water and acid soluble metal fractions, and increased mobility of all metals. Results appear that verify the function of humic acid in improving phytoremediation efficiency of soils contaminated with metals; and potential environmental availability of metals may be controlled by soil amendments with exogenous humic substances. Thus in case metal pollution of soil is a cause of diminished plant growth and yield, the possibility to increase metal availability to plants may represent an advantage when contaminated soil should be reclaimed by phytoextraction process. Results showed that humic acid applications could be used in phytoremediation studies to increase phytoremediation efficiency in contaminated soils.

\section{REFERENCES}

[1] Yu Rui-lian, Yuan Xing, Zhao Yuan-hui, Hu Gong-ren, Tu. Xiang-lin. Heavy metal pollution in intertidalm sediments from Quanzhou Bay, China [J]. Journal of Environmental Sciences, 2008, 20(6): 664-669. https://doi.org/10.1016/S1001-0742(08)62110-5

[2] Lutts, S.; I. Lefevre ; Ch. Delperee; S. Kivits; C. Dechamps; A. Robledo and E. Correal. Heavy metal accumulation by the halophyte species Mediterranean saltbush. J. Environ. Qual., 2004, 33: 1271-1279. https://doi.org/10.2134/jeq2004.1271

[3] Wallace, A., Wallace, G.A. A possible flaw in EPA's 1993 new sludge rule due to heavy metal interactions. Commun. Soil Sci. Plant Anal. 1994, 25, 129-135. https://doi.org/10.1080/00103629409369019

[4] Planquart, P., Bonin, G., Prone, A., Massiani, C. Distribution movement and plant availability of trace metals in soils amended with SS composts: application to low loadings. The Science of the Total Environment, 1999, 241:161-179. https://doi.org/10.1016/S0048-9697(99)00338-1

[5] Yusuf, K.A. Sequental extraction of lead, copper, cadmim and zinc in soils near ojota waste site. Journal of Agronomy , 2007,6(2):331-337. https://doi.org/10.3923/ja.2007.331.337

[6] C.E.C. (Council of the European Communities) Directive of 12 June 1986 on the protection of the environment, and in particular of the soil, when SS is used in agriculture (86/278/CEE). Official Journal of the European Communities, L181, 6-12.

[7] Tessier, A., Campbell, P.G.C., Bison, M. Sequental extraction procedure for the speciation of particulate trace metals. Anal. Chem. 1979, 51, 844-851. https://doi.org/10.1021/ac50043a017

[8] ISO 11466 Inter. Standard, 1995. Soil quality-extraction of trace elements soluble in aqua regia. 03-01.

[9] Lindsay, W.L., Norwell, W.A. Development of a DTPA soil test for zinc, iron, manganese, and copper. Soil sci. Soc. Am. J.,1978, 42, 421-428. https://doi.org/10.2136/sssaj1978.03615995004200030009x

[10] Tessier, A., Campbell, P.G.C., Bison, M. Sequental extraction procedure for the speciation of particulate trace metals. Anal. Chem.., 1979, 51, 844-851. https://doi.org/10.1021/ac50043a017

[11] Stevenson, F.J. Humus chemistry: Genesis, composition and reaction. (second ed.), 1994, Wiley, New York.

[12] McGrath, S.P. Metal concentrations in sludges and soils from a long-term field trial. J. Agric. Sci.,1994, 103, 23-35. https://doi.org/10.1017/S002185960004329X

[13] Clemente, Rafael, and M. Pilar Bernal. "Fractionation of heavy metals and distribution of organic carbon in two contaminated soils amended with humic acids." Chemosphere 64.8 (2006): 1264-1273. https://doi.org/10.1016/j.chemosphere.2005.12.058

[14] Soon, Y.K., Abboud, S. Trace elements in agricultural soils of North-western Alberta. Can.J. Soil Sci., 1990, 70, 277-288. https://doi.org/10.4141/cjss90-029

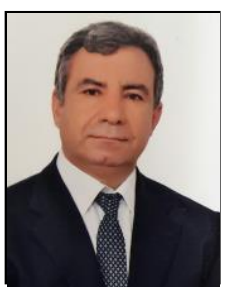

Bülent TOPCUOĞLU has born in Turkey, 1966; obtained PhD degree in 1993 from the Ankara University, Turkey in Soil Science and Plant Nutrition department.

He is currently working as a Professor on Soil Science and Plant Nutrition, Soil Pollution and Environmental Sciences topics, at the Akdeniz University Vocational school of Tecnical Sciences, Antalya TURKEY. Author has done more than one hundred research publication to his credit. 
20th ISTANBUL International Conference on "Agricultural, Biological and Medical Sciences" (IABMS-19) Dec. 5-6, 2019 Istanbul (Turkey)

Prof. Topcuoğlu has a scientific member of many organizations and chaire of many conferences organized by IAAST, IAE, CBMSR, IICBEE, IIENG and PSRC in İstanbul and Antalya, TURKEY. 